Research Article

www.ijrap.net (ISSN:2229-3566)

\title{
CASE REPORT: MANAGEMENT OF CEREBELLAR ATROPHY THROUGH AYURVEDIC MEDICINES
}

Arjun M. ${ }^{* 1}$, Reshma T. ${ }^{2}$

${ }^{1}$ Assistant Professor, PNNM Ayurveda Medical College, Cheruthuruthy, Thrissur, Kerala, India

${ }^{2}$ Chief Physician, Rasayani Ayurveda Speciality Clinic, Kannapuram, Chettupuzha, Thrissur, Kerala, India

Received on: 15/06/19Accepted on: 15/12/19

\author{
*Corresponding author \\ E-mail: drarjunm@gmail.com
}

DOI: $10.7897 / 2277-4343.110118$

\begin{abstract}
Cerebellum is known as little brain and mainly controls and coordinates the movements of the body. It is the second largest part of the brain. The degeneration to the cerebellum results in cerebellar atrophy, which seriously alters the body movements, gait and speech. The ataxic gait also known as cerebellar ataxia is a cardinal symptom of the problem. In this case report, a 54-year-old male came to the OPD complaining of ataxic gait and scanning speech, which was diagnosed as cerebellar atrophy. Ayurvedic treatment mainly comprising of Abhrakabhasma along with Mahakalyanaka ghrita was given to the patient for a period of 50 days and found remarkable improvement in symptoms. The symptoms were assessed using Scale for the assessment and rating of ataxia (SARA), before and after the treatment i.e., on Day 0 and Day 101. The patient's total score changed from 29 to 4 after the treatment. The patient was almost completely recovered within a period of 101 days. No adverse drug reactions were reported during the entire course of treatment. This case report focuses on the effect of Ayurvedic medicines in the management of Cerebellar ataxia as well as Cerebellar atrophy.
\end{abstract}

Keywords: Cerebellar atrophy, ataxia, Abhrakabhasma, Kampavata, Mahakalyanakaghrita

\section{INTRODUCTION}

Recent global epidemiological studies on ataxia have reported an estimated overall prevalence rate of $26 / 100,000$ in children, a prevalence rate of dominant hereditary cerebellar ataxia of $2,7 / 100,000$, and a prevalence rate of recessive cerebellar ataxia of 3,3/100,000. ${ }^{1}$ The condition is almost incurable and requires multidisciplinary management. The cerebellum or little brain is in the posterior cranial fossa. The weight of the cerebellum in the adult is about $150 \mathrm{~g}$. This is about $10 \%$ of the weight of the cerebral hemisphere. Behind the pons and the medulla is the cerebellum. It is separated from the cerebrum by a fold of dura matter called the tentorium cerebelli. The cerebellum consists of a part lying near the midline called the vermis, and of two lateral hemispheres. It has two surfaces; superior and inferior layers. There is no line of distinguishing between vermis and hemispheres on the superior aspect. On the inferior aspect, a deep depression called the vallecula separates the two hemispheres. A series of fissures that run more or less parallel to each other outline the surface of the cerebellum. The primary fissure and the posterolateral fissure are the deepest fissures in the cerebellum. These fissures divide the cerebellum into three lobes; the anterior lobe, the posterior lobe and the flocculonodular lobe. The anterior and posterior lobes together form the corpus cerebelli. ${ }^{2}$

The cerebellar structures controlling eye movements include the so-called oculomotor vermis (lobules VI and VII) and fastigius nucleus, crus I-II of ansiform lobule, flocculus and paraflocculus, uvula and nodulus. Speech is controlled by the superior paravermal region, the intermediate cerebellar cortex, and the dentate nucleus. Limb movements are under the supervision of the dentate nucleus, the inter positus nucleus, the intermediate cerebellar cortex and the lateral cerebellar cortex. Stance/gait is controlled by the medial and intermediate cerebellum. Cognitive operations are mainly controlled by the posterior lobe (posterolateral cerebellum) and cerebellar nuclei (mainly parts of dentate nuclei) ${ }^{3}$

Cerebellum degeneration is characterised by the deterioration of the area of the brain concerned with balance and muscle coordination. The Subacute cerebellar degeneration is divided into two; paraneoplastic cerebellar degeneration; which sometimes precedes cancer diagnosis and alcoholic or nutritional cerebellar degeneration due to vitamin B-1 deficiency. These two types have symptoms in common, but not the same cause. Common symptoms include weakened muscle coordination of the limbs, dysarthria, dysphagia, loss of reason (dementia), involuntary rapid movements of the eyeball in a horizontal or vertical direction (nystagmus), diplopia, vertigo, paralysis of eye muscles (ophthalmoplegia) and difficulty in walking if the patient has alcoholic/nutritional cerebellar degeneration. ${ }^{4}$ The patho physiology of ataxia is being progressively understood and linked to the functional organization of the cerebellum. The impact of cerebellar diseases on different neurologic functions has been better defined and shown not to be limited to loss of motor coordination. The role of autoimmunity is increasingly recognized as a cause of sporadic causes of ataxia. ${ }^{5}$ This condition can seriously affect the tissues of the central nervous system including the spinal cord, brainstem and cerebral cortex. It is an incurable condition and maybe fatal if not treated. Vitamin supplementation, Occupational therapy, Physical therapy and speech therapy are used in the management of Cerebellar atrophy.

Ayurveda is a system of medicine, which has given prime importance to the brain and brain related problems. Ayurveda mentions head as Siras and mentions it as the seat of kapha. Any degeneration causes depletion of kapha and ultimately resulting in the vitiation of vayu. So medicines often given to the diseases affecting the brain i.e., mainly of neurological origin are usually Snigdha (unctuous) in nature. Formulations made of Ghrita (clarified butter) and Tailam (sesame oil) play a key role in 
treating such conditions. In addition to many procedures such as Moordhatailam, Panchakarma procedures etc have proven results in neurological conditions. A previous case report using Panchakarma therapy proved significant improvement of Spinocerebellar ataxia. ${ }^{6}$ Cerebellar atrophy is also a serious condition and role of Ayurvedic medicines are yet to be explored. It can be compared to Kampa(Vepathu) mentioned in Ayurvedic texts and the treatment is vatachikitsa. The assessment of symptoms was done using the Scale for the Assessment and Rating of Ataxia (SARA) ${ }^{7}$ and MRC- Scale. ${ }^{8}$

\section{METHODOLOGY}

A 54-year-old Indian male came to the OPD a few months back, supported by two men on the shoulders with a 'drunkard gait'. He was a lean man, weighed $49 \mathrm{~kg}$ and a height of 5 feet 4 inches. Also had a scanning speech (dysarthria), hoarseness of voice, general debility and pallor for the past 6 months. He was not able to walk without support even for a few metres. He had difficulty to hold things such as glass, plates etc. He had mild stiffness and pain on movements. The patient has no history of T2 Diabetes Mellitus, Hypertension or any other systemic illness. But appetite was reduced and has sleep disturbances due to sleep deprivation. The symptoms started 6 months back and took treatment in a local hospital. The hospital authorities examined thoroughly and diagnosed as a case of cerebellar atrophy. The patient became weak day by day and had to quit his job and discontinued the treatment in the local hospital and came to our hospital to take Ayurvedic treatment. On examination, it was revealed that the person had no signs of alcohol consumption and he told that he has not at all consumed alcohol ever in his life. The routine biological examinations were done. The blood sugar levels and the blood pressure were within the normal limits. Neurological examination and locomotor examinations were done carefully and assessed using SARA (Table 1). It was found that the muscle power is Grade 3 using MRC- scale (Table 2). Muscle tone was also reduced (Hypotonia Asthenia). The computerised tomographic scan impression of the patient was

1. Cerebellar atrophy

2. Lacunar infarct in the Left gangliocapsular region.

The disease was manifested due to the vitiation of vata and the lakshana was sarvangakampata. So, it was diagnosed as Kampaor Vepathu and the treatment is Kevalavata chikitsa according to Ayurvedic classical texts. ${ }^{9}$ The treatment for the patient started with amapachana drugs.

\section{Treatment given}

$0^{\text {th }}$ day

Indukanthamkashayam $90 \mathrm{ml}$ bid $(\mathrm{a} / \mathrm{c})$

Shaddharanam tablet $1 \mathrm{~g}$ bid $(\mathrm{a} / \mathrm{c})$

$7^{\text {th }}$ day

Mahakalyanakaghritam $10 \mathrm{ml}$ bid

Ksheerabala 21 times - 2 drops in each nostril in the morning and for external application over the scalp.

Dhanwantaramtailam - for external application over the body $21^{\text {st }}$ day

Abhrakabhasma $200 \mathrm{mg}$ with Mahakalyanakaghritam $10 \mathrm{ml}(\mathrm{p} / \mathrm{c})$ OD

Ksheerabalatailam for external application over the scalp Dhanwantaramtailam for external application over the body

$71^{\text {st }}$ day

Dhanadanayanadikashayam $90 \mathrm{ml}$ bid (a/c)

Ksheerabalatailam 101 times along with kashaya

Indukanthamghritam $10 \mathrm{ml}$ with rice water OD at bed time

Dhanwantaramtailam for external application over the body

$101^{\text {st }}$ day

Aswagandharasayanam $10 \mathrm{~g}(\mathrm{p} / \mathrm{c})$ at bed time

\section{Ethical consideration}

The study is carried out as per Declaration of Helsinki guidelines.

\section{General consent}

The general consent from the patient was obtained before starting the treatment.

\section{RESULTS AND DISCUSSION}

Kampa or Vepathu is a condition which is mentioned in Ayurveda texts, in which tremors occur on all organs especially on the limbs. It is assumed to be due to the vayukopa in the body. Usually it occurs without any pre symptoms and signs, which is a nature of Vatavyadhi. Kampa (tremors/shivering) occurs also due to Pitta kshaya in the body and in another vatavyadhi named kalayakhanja. Usually tremors occurring without symptoms are manifested as Vatakopa or vatavyadhi. Vatakopa occurs due to excessive consumption of Tikta rasa and Kashaya rasa (bitter and astringent tastes, Ushna (hot), pramitha (untimely) and alpa (less in quantity or deficiency) bhojana (food).${ }^{10}$ Nishijagarana (sleep deprivation at night) etc. also leads to vatakopa.

Parkinsonism is usually compared to Kampa or Vepathu. It occurs due to the ill functioning of Basal ganglia. Ataxia occurs due to the dysfunction of cerebellum (Table 3).

The vata is relatively higher in cerebellar atrophy in contrast with Parkinsonism. In Parkinsonism, Vatakapha involvement is higher. Vitiation of Vata may occur due to srotorodha or dhatukshaya. ${ }^{12}$ In such conditions, application of sneha (unctuous substances) such as medicated ghrita and taila, internally as well as externally are suggested as line of treatment in Ayurveda.

Here there is evident kshaya of an organ. Initially, the patient had stiffness and pain on movements; also a reduced appetite and weakness. So on Day 0, Indukanthamkashayam and Shaddharanam tablet was chosen as amapachana for internal administration and without any external application. On Day 7, after attaining proper appetite and a mild relief in stiffness and pain, Mahakalyanakaghritam $10 \mathrm{ml}$ was given twice daily along with Ksheerabala Taila 21 times as Nasya and Moordhataila. Medicines are mostly administered at bed time for ailments affecting the head for better results. ${ }^{13}$ 
Table 1: Scale for the assessment and rating of ataxia (SARA)

\begin{tabular}{|c|c|}
\hline 1. & Gait \\
\hline 0 & Normal, no difficulties in walking, turning and walking tandem \\
\hline 1 & Slight difficulties, only visible when walking 10 connective steps in tandem \\
\hline 2 & Clearly abnormal, tandem walking $>10$ steps not possible \\
\hline 3 & Considerably staggering, difficulties in half-turn, but without support \\
\hline 4 & Marked staggering, intermittent support of the wall required \\
\hline 5 & Severe staggering, permanent support of stick or light support by one arm required \\
\hline 6 & Walking $>10 \mathrm{~m}$ only with strong support (two special sticks or stroller or accompanying person \\
\hline 7 & Walking $<10 \mathrm{~m}$ only with strong support (two special sticks or stroller or accompanying person) \\
\hline 8 & Unable to walk, even supported \\
\hline 2. & Stance \\
\hline 0 & Normal, able to stand in tandem for $>10$ seconds \\
\hline 1 & Able to stand with feet together without sway not in tandem for $>10$ seconds \\
\hline 2 & Able to stand with feet together for $>10$ seconds, but only with sway \\
\hline 3 & Able to stand for $>10$ seconds without support in natural position, but not with feet together \\
\hline 4 & Able to stand for $>10$ seconds in natural position only with intermittent support \\
\hline 5 & Able to stand for $>10$ seconds in natural position only with constant support of one arm \\
\hline 6 & Unable to stand for $>10$ seconds even with constant support of arm \\
\hline 3. & Sitting \\
\hline 0 & Normal, no difficulties sitting $>10$ seconds \\
\hline 1 & Slight difficulties, intermittent sway \\
\hline 2 & Constant sway but able to sit $>10$ seconds with support \\
\hline 3 & Able to sit $>10$ seconds only with intermittent support \\
\hline 4 & Unable to sit $>10$ seconds without continuous support \\
\hline 4. & Speech disturbance \\
\hline 0 & Normal \\
\hline 1 & Suggestion of speech disturbance \\
\hline 2 & Impaired speech, but easy to understand \\
\hline 3 & Occasional words difficult to understand \\
\hline 4 & Many words difficult to understand \\
\hline 5 & Only single words understandable \\
\hline 6 & Speech unintelligible/ anarthria \\
\hline 5. & Finger chase \\
\hline 0 & No dysmetria \\
\hline 1 & Dysmetria, under / overshooting target $<5 \mathrm{~cm}$ \\
\hline 2 & Dysmetria, under / overshooting target $<15 \mathrm{~cm}$ \\
\hline 3 & Dysmetria, under / overshooting target $>15 \mathrm{~cm}$ \\
\hline \multirow[t]{2}{*}{4} & Unable to perform 5 pointing movements \\
\hline & Mean of Right and Left side are taken \\
\hline 6. & Nose finger mean test \\
\hline 0 & No tremor \\
\hline 1 & Tremor with an amplitude $<2 \mathrm{~cm}$ \\
\hline 2 & Tremor with an amplitude $<5 \mathrm{~cm}$ \\
\hline 3 & Tremor with an amplitude $>5 \mathrm{~cm}$ \\
\hline \multirow[t]{2}{*}{4} & Unable to perform 5 pointing movements \\
\hline & Mean of Right and Left side are taken \\
\hline 7. & Fast alternating hand movements \\
\hline 0 & Normal, no irregularities (perform $<10$ seconds) \\
\hline 1 & Slightly irregular (perform $<10$ seconds) \\
\hline 2 & Clearly irregular, single movements difficult to distinguish or relevant interruptions, but performs $<10$ seconds \\
\hline 3 & Very irregular, single movements difficult to distinguish or relevant interruptions, performs $>10$ seconds \\
\hline \multirow[t]{2}{*}{4} & Unable to complete 10 cycles \\
\hline & Mean of Right and Left side are taken \\
\hline 8. & Heel - shin slide \\
\hline 0 & Normal \\
\hline 1 & Slightly abnormal, contact to shin maintained \\
\hline 2 & Clearly abnormal, goes off shin up to 3 times during 3 cycles \\
\hline 3 & Severly abnormal, goes off shin 4 or more times during 3 cycles \\
\hline \multirow[t]{2}{*}{4} & Unable to perform the task \\
\hline & Mean of Right and Left side are taken \\
\hline
\end{tabular}

Table 2: MRC Scale for testing Muscle Power

\begin{tabular}{|ll|}
\hline 0 & No contraction \\
1 & Flicker or trace of contraction \\
2 & Active movement, with gravity eliminated \\
3 & Active movement against gravity \\
4 & Active movement against gravity and resistance \\
5 & Normal power \\
\hline
\end{tabular}


Arjun M. and Reshma T. / Int. J. Res. Ayurveda Pharm. 11 (1), 2020

Table 3: Differences in symptoms of Basal ganglia and Cerebellar dysfunction

\begin{tabular}{|c|c|}
\hline Basal ganglia dysfunction & Cerebellar dysfunction \\
\hline Increased muscle tone & Decreased muscle tone \\
\hline Resting tremors & Intentional tremors \\
\hline Pill rolling movement & Nothing specific \\
\hline Occurs in elderly due to deficiency of dopamine & Maybe genetical or without specific reasons \\
\hline Stiff, shuffling gait & Cerebellar gait \\
\hline Mask like facial expression & Nothing specific \\
\hline Stooped posture due to rigidity & Nothing specific \\
\hline
\end{tabular}

Table 4: Patient's score

\begin{tabular}{|c|c|c|}
\hline Test & Score Before treatment & Score After treatment \\
\hline Gait & 7 & 1 \\
\hline Stance & 5 & 1 \\
\hline Sitting & 3 & 0 \\
\hline Speech disturbance & 5 & 1 \\
\hline Finger chase & $\mathrm{R}=2, \mathrm{~L}=2$, Average 2 & $\mathrm{R}=0, \mathrm{~L}=0$, Average 0 \\
\hline Nose finger mean test & $\mathrm{R}=2, \mathrm{~L}=2$, Average 2 & $\mathrm{R}=0, \mathrm{~L}=0$, Average 0 \\
\hline Fast alternating hand movements & $\mathrm{R}=3, \mathrm{~L}=3$, Average 3 & $\mathrm{R}=0, \mathrm{~L}=0$, Average 0 \\
\hline Heel - shin slide & $\mathrm{R}=2, \mathrm{~L}=2$, Average 2 & $\mathrm{R}=1, \mathrm{~L}=1$, Average 1 \\
\hline Total score & $\mathbf{2 9}$ & $\mathbf{0 4}$ \\
\hline
\end{tabular}

Ksheerabalataila owing to vatahara properties was chosen for Pratimarsha Nasya. The Moordhataila prayoga was done as just application of the oil over the scalp. Usually Nasya is considered for the ailments affecting the head. But no significant response was obtained even after 14 days of the administration. So we thought of giving Abhrakabhasma. On Day 21, Abhrakabhasma $200 \mathrm{mg}$ along with Mahakalyanakaghrita was selected for internal administration. The time of administration was limited to once daily as it is a mineral formulation. Abhrakabhasma is vata pitta kshayaghna (pacifies vata and pitta), prajna Bodhi (boosts intelligence and cognition), rujaprashamana (pain reliever), vrishya (improves libido) and ayushya (promotes longevity). It is also balya (increases strength), snigdha (unctuous), ruchida (appetizer), akapha (pacifies kapha), deepana (carminative) and of seetaveerya (cold potency). ${ }^{14}$ It is considered as a rasayana. Studies show it has remarkable effect on nervous system and improving intellect. Mahakalyanakaghrita is a potent formulation, mainly administered for ailments related to head and intelligence. ${ }^{15}$ The patient showed significant improvement from symptoms after 50 days of administration of Abhrakabhasma. To avoid Satmya, patient was reviewed on $71^{\text {st }}$ day and medicines were modified. Abhrakabhasma was withdrawn and Dhanadanayanadikashayam $90 \mathrm{ml}$ twice daily was given along with Ksheerabalatailam 101 times. Indukanthamghritam $10 \mathrm{ml}$ was given once daily with rice water at bed time. These medicines were given for a period of 30 days. Also, Lacunar infarcts found on the left gangliocapsular region increases the risk of a stroke. So Dhanadanayanadi Kashaya and Indukanthaghrita was chosen to pacify vata even after discontinuing Abhrakabhasma. On $101^{\text {st }}$ day, the patient was examined and found good relief from symptoms.

The reassessment was done using SARA and score was calculated. The muscle power was calculated using MRC scale. The patient showed very much improvement in gait. He was able to walk 100 metres without support. The stance and sitting showed good improvement. The speech had a little disturbance, even though the patient was able to communicate almost clearly. The nose finger test was done without tremor with both hands. The patient was able to perform Fast alternating hand movements on an average of 7 times in 10 seconds. Heel - shin slide test was performed comparatively better. The improvement in patient's score shows the effect of medicine for the relief of symptoms. The initial score (before treatment) was 29 and it changed to 4 after 101 days of treatment (Table 4). The grade of muscle power was 3 which became 4 after the treatment. Aswagandharasayana $10 \mathrm{~g}$ once daily was given to the patient for another two months as a follow up treatment. It promotes strength and improves the muscle tone. No adverse reactions were observed during the entire course of the treatment. More researches have to be done in this area to highlight a better management for such conditions which are considered incurable. An IP level treatment comprising of Panchakarma therapy etc may invoke better result.

\section{MRC Scale}

The patient had a muscle power of Grade 3 before treatment and Grade 4 after treatment.

\section{CONCLUSION}

From this case report, it is assumed that Ayurvedic medicines can offer better management to a probably incurable condition like cerebellar atrophy. Here a patient diagnosed as cerebellar atrophy (cerebellar degeneration) was treated with Ayurvedic medicines and got relief from symptoms in almost 101 days of treatment. Abhrakabhasma, a unique mineral formulation, which is very cost effective mentioned in Ayurvedic texts as a brain stimulator was administered along with Mahakalyanakaghrita for a period of 50 days and the patient showed significant improvement of symptoms. Ayurvedic medicines have a vital role in reducing the symptoms of cerebellar atrophy. The pre and post assessment was done using SARA. Also the medicines contributed in improving the general health of the patient. More studies have to be conducted on the effect of Abhrakabhasma in such neurological conditions. An integrated approach consisting of Ayurvedic medicines along with Panchakarma therapy, occupational and physical therapy may produce good results in managing Cerebellar atrophy.

\section{ACKNOWLEDGEMENT}

Department of Rasasastra and Bhaishajya Kalpana, Government Ayurveda College, Thiruvananthapuram and PNNM Ayurveda Medical College and Hospital Cheruthuruthy, Thrissur. 


\section{REFERENCES}

1. Salman MS, Cerebellum. 2018; 17(1): 4-11. DOI: 10.1007/s12311-017-0885-2.

https://www.ncbi.nlm.nih.gov/m/pubmed/28940047/

2. Inderbir Singh, Textbook of Human Neuroanatomy (Fundamental and Clinical), Gross Anatomy of the Cerebellum, eighth edition, New Delhi, Jaypee Brothers Medical Publishers (P) Ltd; 2009. p. 73-74.

3. Manto M, Bower JM, Conforto AB, Delgado-García JM, da Guarda SN, Gerwig M, et al. Consensus paper: roles of the cerebellum in motor control-the diversity of ideas on cerebellar involvement in movement. Cerebellum. 2012; 11: 457-87. Pub Med Google Scholar https://www.ncbi.nlm.nih.gov/pubmed/22161499

4. Rare-diseases.org, Connecticut: National Organization for Rare Disorders, Inc. updated 2019. p. 1. https://rarediseases.org/rare-diseases/cerebellardegeneration-subacute/

5. Pandolfo, Massimo \&Manto, Mario. Cerebellar and Afferent Ataxias. Continuum (Minneapolis, Minn.). 19. 1312-1343. 10.1212/01.CON.0000436158.39285.22. 2013. p. 1 . https://insights.ovid.com/crossref?an=00132979201310000-00014

6. Singh SK, Rajoria K. Ayurvedic approach in the management of spinocerebellar ataxia-2. Anc Sci Life 2016; 35(3): 167172. DOI: $10.4103 / 0257-7941.179873 ; 2016$. p. 5 . https://www.ncbi.nlm.nih.gov/pmc/articles/PMC4850777/

7. Physio-pedia.com, England, Free source of Physical therapy knowledge; 2019. p. 2. https://www.physiopedia.com/Scale_for_the_Assessment_and_Rating_of_Ataxi a_(SARA)
8. Medical research council Memorandum No. 45 (superseding War Memorandum No. 7) Aids to the examination of the peripheral nervous system, London, Her Majesty's Stationery Office, Crown Copyright; 1976. p. 1.

9. Agnivesa, Caraka Samhita of Agnivesa, Reprint Edition, Varanasi, Chaukhambha Prakashan, Chikitsasthana Chapter 28, Vatavyadhi Chikitsitamp; 2010. p. 616.

10. Vagbhata, Ashtanga Hridaya, Reprint Edition, Varanasi, Chaukhambha Surbharati Prakashan. Nidanasthana Chapter 1, Sarvaroganidanam; 2010. p. 444.

11. Vishram Singh, Textbook of Clinical Neuroanatomy, $1^{\text {st }}$ edition, New Delhi, Elsevier, Chapter 13, Basal Nuclei; 2004. p. 209.

12. Vagbhata, Ashtanga Hridaya, Reprint Edition, Varanasi, Chaukhambha Surbharati Prakashan, Nidanasthana Chapter 15, Vatavyadhi Nidanam; 2010. p. 530-531.

13. Vagbhata, Ashtanga Hridaya, Reprint Edition, Varanasi, Chaukhambha Surbharati Prakashan, Sutrasthana Chapter 13, Doshopakramaneeyam; 2010. p. 219.

14. Indradev Tripathi, Rasaratnasamuchaya of Vagbhatacharya, Reprint Edition, Varanasi, Chaukhambha Sanskrit Sansthan, Chapter 2, Maharasa; 2013. p. 10.

15. K.V. Krishnan Vaidyar, S. Gopala Pillai, Sahasrayogam Commentary, $30^{\text {th }}$ Edition, Alappuzha, Vidyarambham Publishers; 2011. p. 349-350.

\section{Cite this article as:}

Arjun M. and Reshma T. Case Report - Management of Cerebellar Atrophy through Ayurvedic medicines. Int. J. Res. $\begin{array}{lll}\text { Ayurveda } & \text { Pharm. 2020;11(1):91-95 }\end{array}$ http://dx.doi.org/10.7897/2277-4343.110118

Disclaimer: IJRAP is solely owned by Moksha Publishing House - A non-profit publishing house, dedicated to publish quality research, while every effort has been taken to verify the accuracy of the content published in our Journal. IJRAP cannot accept any responsibility or liability for the site content and articles published. The views expressed in articles by our contributing authors are not necessarily those of IJRAP editor or editorial board members. 